\title{
Učinek kognitivnega računalniškega treninga pri aktivnih starejših odraslih
}

\author{
Karin Bakračevičl* ${ }^{*}$, Veronika Horvat ${ }^{1}$, Vojko Kavčič ${ }^{2,3}$ in Anja Knez \\ ${ }^{1}$ Oddelek za psihologijo, Filozofska fakulteta, Univerza v Mariboru \\ ${ }^{2}$ Institute of Gerontology, Wayne State University, Detroit, MI, ZDA \\ ${ }^{3}$ Mednarodni inštitut za aplikativno gerontologijo, Ljubljana
}

\begin{abstract}
Povzetek: Staranje populacije in z njim povezani kognitivni upadi so s seboj prinesli povečano zanimanje za kognitivni računalniški trening kot eno od možnosti za ohranjanje kognitivnih sposobnosti. Namen naše raziskave je bil preveriti učinek kognitivnega računalniškega treninga na kognitivne sposobnosti ter povezanost tega učinka s predhodnimi kognitivnimi sposobnostmi in zadovoljstvom z življenjem pri populaciji aktivnih starejših odraslih. V raziskavo je bilo vključenih 46 udeležencev, od tega jih je bilo 25 deležnih kognitivnega računalniškega treninga, ostali pa so predstavljali pasivno kontrolno skupino. Obe skupini smo testirali $\mathrm{s}$ testno baterijo pred in po zaključeni intervenciji. Testna baterija je bila sestavljena iz demografskega vprašalnika in objektivnih testov kognitivnih sposobnosti. Rezultati so pokazali učinke kognitivnega računalniškega treninga na vidnoprostorske sposobnosti, pozornost, kratkotrajni in delovni spomin. V skladu s predvidevanji pa se razlike niso pokazale pri verbalnih sposobnostih. Prav tako smo ugotovili večji učinek kognitivnega računalniškega treninga pri posameznikih z nižjimi kognitivnimi sposobnostmi na vidnoprostorskem področju, na področju kratkotrajnega spomina, verbalne fluentnosti in hitrosti procesiranja informacij.
\end{abstract}

Ključne besede: kognitivni računalniški trening, aktivni starejši odrasli, kognitivne sposobnosti, zadovoljstvo z življenjem

\section{The effect of cognitive computer training in active older adults}

\author{
Karin Bakračevič ${ }^{*}$, Veronika Horvat ${ }^{1}$, Vojko Kavčič ${ }^{2,3}$ and Anja Knez \\ ${ }^{1}$ Department of Psychology, Faculty of Arts, University of Maribor, Slovenia \\ ${ }^{2}$ Institute of Gerontology, Wayne State University, Detroit, MI, USA \\ ${ }^{3}$ International Institute of Applied Gerontology, Ljubljana, Slovenia
}

\begin{abstract}
Ageing of population and related cognitive decline have contributed to an increased interest in cognitive computer training as one of options for maintaining cognitive abilities. Our research was aimed at verifying how cognitive computer training affected cognitive abilities as well as how it was connected with initial cognitive abilities and life satisfaction of active older adults. The research comprised 46 subjects of whom 25 received cognitive computer training and the remainder were assigned to a passive control group. Before and after the intervention, both groups were tested with a test battery which consisted of a demographic questionnaire and objective tests of cognitive abilities. The outcomes showed a statistically significant effects of cognitive computer training on visuospatial abilities and attention, as well as on short-term memory and working memory. However, there was no notable difference in verbal domain, as had been anticipated. We have also noticed profound effects of cognitive computer training on individuals with lower cognitive abilities in visuo-spatial domain, short-term memory, verbal fluency and information processing speed.
\end{abstract}

Keywords: cognitive computer training, active older adults, cognitive abilities, life satisfaction

\footnotetext{
"Naslov/Address: dr. Karin Bakračevič, Oddelek za psihologijo, Filozofska fakulteta, Univerza v Mariboru, Koroška cesta 160, Maribor,
} e-mail: karin.bakracevic@um.si

Članek je licenciran pod pogoji Creative Commons Attribution 4.0 International licence. (CC-BY licenca).

The article is licensed under a Creative Commons Attribution 4.0 International License (CC-BY license). 


\section{Starejši odrasli in uspešno staranje}

Tako kot drugod po svetu, tudi v Sloveniji opažamo porast populacije $\mathrm{v}$ obdobju pozne odraslosti, prav tako pa raziskave kažejo, da bo z leti še naraščala tudi pričakovana življenjska doba obeh spolov (European Commission, 2018). To spoznanje vse bolj kliče po iskanju najrazličnejših možnosti, kako posameznikom v tem obdobju omogočiti čim bolj dostojanstveno in kar se da minimalno spremenjeno življenje v primerjavi s tistim, ki so ga bili vajeni (Sedmak idr., 2017).

Levinson (1986) pozno odraslost opredeljuje kot zadnje obdobje odraslosti, ki se prične med 60. in 65. letom starosti. $\mathrm{V}$ to obdobje se uvrščajo posamezniki, za katere uporabljamo izraz starejši odrasli.

Svetovna zdravstvena organizacija uspešno staranje opredeljuje kot proces, ki posameznike v obdobju staranja spodbuja, jim daje možnosti za zdravje in vključevanje v družbo ter varnost, ki jim omogoča kakovostno življenje v starosti (Nacionalni inštitut za javno zdravje, 2016). Za starejše odrasle je zelo pomembna fizična, mentalna in socialna dejavnost, pri čemer pa na uspešno staranje gledamo kot na kompleksno celoto različnih dejavnikov, ki omogočajo ohranjanje sposobnosti in pripomorejo k temu, da življenje v starosti ne postane pasivno (Stenner idr., 2011). Tako aktivno staranje opredeljuje stalno vključevanje v dejavnosti, ki segajo na socialno, gospodarsko in kulturno področje ter pomagajo pri dejavnostih vsakdanjega življenja (Walker, 2006). Za uspešno staranje je ključnega pomena kakovost in ne količina dejavnosti, ki si jih posamezniki izberejo, prav tako pa je pomembno, da je dejavnost subjektivno smiselna in zanje zanimiva (Litwin in Shiovitz-Ezra, 2006).

\section{Spremembe kognitivnih sposobnosti s starostjo}

Kot poroča Park (2000), kognitivne sposobnosti, med katere se uvrščajo izvršilne funkcije, pozornost, verbalni in vidni eksplicitni spomin, delovni spomin, vidnoprostorske sposobnosti ter hitrost procesiranja informacij, s starostjo upadajo. Sposobnosti, ki v večji meri temeljijo na izkušnjah in med katere uvrščamo semantični spomin, razumevanje ter besedišče, pa lahko v poznejših obdobjih življenja ostanejo stabilne ali celo naraščajo.

\section{Zadovoljstvo z življenjem v pozni odraslosti}

Zadovoljstvo z življenjem v pozni odraslosti je najpogosteje opredeljeno kot objektiven niz socialno-materialnih meril, ki določajo pogoje posameznikovega življenja in prispevajo h kakovostnemu življenju starostnikov, še bolj pa ga opredeljujejo subjektivne ocene različnih življenjskih pogojev (Smith idr., 1999). Zadovoljstvo z življenjem predstavlja tudi subjektivno kognitivno mero kvalitete posameznikovega življenja, zato je povezanost med njima visoka (Pinquart in Sörensen, 2000).

Pomembno spoznanje je, da tisti posamezniki, ki v starosti ostajajo kompetentni in aktivni, poročajo o višjem zadovoljstvu z življenjem (Pinquart in Sörensen, 2000). S področjem zadovoljstva $\mathrm{z}$ življenjem lahko povežemo tudi t. i. navidezen Matejev učinek (angl. pseudo-Matthew effect), ki se nanaša na kvaliteto življenja in kognitivno delovanje posameznika, saj predvideva, da bodo posamezniki, ki se jim zdi, da dobro kognitivno funkcionirajo ali ocenjujejo svoje življenje kot kvalitetno, pokazali večji učinek treninga v primerjavi s tistimi, ki svoje kognitivno funkcioniranje in kvaliteto življenja ocenjujejo kot nižjo (McDougall in House, 2012).

\section{Kognitivni računalniški trening}

Zaradi trenda naraščanja deleža starejših oseb v populaciji, ki povzroča številne gospodarske in socialne probleme, si moramo prizadevati za podaljšanje aktivnega življenja starejših posameznikov in njihove neodvisnosti (Klimova, 2016). To lahko poskušamo doseči tudi s kognitivnim treningom.

Kognitivni trening predstavlja treniranje uporabe različnih spretnosti in strategij na vodenih nalogah, ki vključujejo urjenje različnih kognitivnih sposobnosti (Mowszowski idr., 2010). Cilj posebej oblikovanih programov treniranja s standardiziranim naborom kognitivnih nalog je izboljšanje sposobnosti na enem ali več kognitivnih področjih (Martin idr., 2011). Ob spodbudnih rezultatih učinkov kognitivnih treningov se je pričela pojavljati težnja k čim večji dostopnosti tovrstnih treningov širšemu krogu posameznikov. S tehnološkim razvojem je bilo to omogočeno s programsko opremo, s pomočjo katere je kognitivni trening mogoče izvajati na računalniku (Klimova, 2016).

Za uspešnost kognitivnega računalniškega treninga morajo biti izpolnjeni določeni pogoji. Izvajati ga je treba $\mathrm{v}$ daljšem časovnem obdobju (Walton idr., 2015), prav tako pa mora biti, če želimo doseči njegovo učinkovitost, intenziven (Haesner idr., 2015). Lampit idr. (2014) navajajo, da bi naj učinkovit trening trajal več kot 30 minut in naj bi potekal največ trikrat tedensko, saj ima $\mathrm{v}$ nasprotnem primeru ravno obraten učinek. Avtorji poudarjajo, da nenadzorovan trening na domu ni učinkovit in da ima računalniška oblika kognitivnega treninga pri zdravih starejših odraslih zmerne učinke pri izboljšanju določenih kognitivnih sposobnosti, pri čemer so učinki odvisni od oblike treninga. Kot poročajo Peretz in sodelavci (2011), pride do najboljšega izboljšanja kognitivnih sposobnosti pri tistih posameznikih, ki imajo nižje kognitivne sposobnosti, ne glede na obliko treninga.

\section{Učinki kognitivnega treninga na kognitivne sposobnosti in zadovoljstvo z življenjem}

V nadaljevanju bomo predstavili nekaj kognitivnih sposobnosti, ki jih naslavlja naša raziskava, in izpostavili ključne podatke ter raziskovalne izsledke s področja uporabe kognitivnega računalniškega treninga.

$\mathrm{Na}$ področju verbalnih sposobnosti, ki predstavljajo izražanje zapisanih in/ali izrečenih besed ter njihovo fluentnost in razumevanje (Palta idr., 2016), V. Klusmann s sodelavci (2010) ugotavlja, da po izvedbi kognitivnega treninga ni statistično pomembnih sprememb v številu različnih kategorij, kamor se uvrščajo navedene besede posameznika (tj., v semantični verbalni fluentnosti). Njenim ugotovitvam 
se pridružujejo Buschkuehl idr. (2008) ter Jackson idr. (2012). Raziskave kognitivnega treninga s področja pozornosti, ki je pogoj vseh razumskih dejavnosti (zaznavanja, učenja, mišljenja in spominjanja; Pečjak, 1998), ugotavljajo večinoma pozitivne učinke na to sposobnost (Ballesteros idr., 2014, 2015; Barban idr., 2016; Basak idr., 2008; Cassavaugh in Kramer, 2009; Cheng idr., 2012; Lee idr., 2013; Mayas idr., 2014; Oswald idr., 2006; Zelinski idr., 2011). Po drugi strani pa Lampit s sodelavcema (2014) o učinku kognitivnega treninga na pozornost ne poroča. Na področju izvršilnih funkcij, ki vključujejo načrtovanje in kognitivno prilagajanje (Kueider idr., 2012), številne raziskave ugotavljajo izboljšanje sposobnosti izvršilnih funkcij po izvedenem kognitivnem treningu (Basak idr., 2008; Buiza idr., 2007; Cassavaugh in Kramer, 2009; Karbach in Verhaeghen, 2014; Kelly idr., 2014; Maillot idr., 2012; Nouchi idr., 2012; Winocur idr., 2007). Ponovno pa nekatere raziskave ne potrjujejo pomembnega učinka kognitivnega treninga na izvršilne funkcije (Lampit idr., 2014).

S starostjo hitrost procesiranja informacij pomembno upada in vodi $\mathrm{k}$ slabšemu kognitivnemu delovanju (Salthouse, 1996). O pozitivnem učinku kognitivnega treninga na hitrost procesiranja informacij poročajo številne raziskave (Ball idr., 2002, 2007; Ballesteros idr., 2014, 2015; Bavelier idr., 2011; Cheng idr., 2012; Edwards idr., 2002; Jak idr., 2013; Kelly idr., 2014; Lampit idr., 2014; Mahncke idr., 2006; Oswald idr., 2006; Vance idr., 2007; Zelinski idr., 2011). O izboljšanju kratkoročnega spomina, torej omejenega pomnilniškega sistema, ki informacije $\mathrm{v}$ določenem zaporedju hrani nekaj sekund ali minut (Brickman in Stern, 2009), po izvedenem kognitivnem treningu poročajo Barban idr. (2016), Borella idr. (2010), Buiza idr. (2007), Cheng idr. (2012), Giuli idr. (2016), Kelly idr. (2014), Mahncke idr. (2006), McAvinue idr. (2013) in Miller idr. (2013). Richmond idr. (2011) pa učinka kognitivnega treninga na kratkoročni spomin niso ugotovili.

Začasno hrambo in manipuliranje $\mathrm{z}$ informacijami omogoča delovni spomin (Baddeley, 1992), pri katerem je večina raziskovalcev enotnega mnenja, da ima nanj kognitivni trening pozitiven učinek (Carretti idr., 2011; Hardy idr., 2015; Karbach in Verhaeghen, 2014; Kelly idr., 2014). Vidnoprostorske sposobnosti vključujejo sposobnost manipuliranja in razvrščanja objektov $\mathrm{v}$ pozicijske relacije $\mathrm{v}$ prostoru (Palta idr., 2016), sposobnost prostorske navigacije pa se nanaša na proces ugotavljanja in vzdrževanja poti od ene do druge lokacije (Lithfous idr., 2013). Metaanaliza Uttala in sodelavcev (2013) ugotavlja, da so prostorske sposobnosti dovzetne za prostorski kognitivni trening, ki ima lahko tudi dolgoročne učinke, ki se prenašajo tudi na naloge, ki niso neposredno trenirane.

Vedno bolj se izpostavlja tudi pomen samoocenjevanja kognitivnih sposobnosti $\mathrm{v}$ študijah kognitivnega treninga oz. subjektivnega vrednotenja njegovih učinkov. Študije poročajo o doprinosu kognitivnega treninga $\mathrm{k}$ različnim področjem psihičnega delovanja (Buitenweg idr., 2019). Ugotavljajo neposredno izboljšanje pozitivnega samovrednotenja (Burgener idr., 2008), vsakodnevnega funkcioniranja (Corbett idr., 2015), kvalitete življenja (Wolinsky idr., 2006) ali zmanjšanja depresivne simptomatike (Calkins idr., 2015).

\section{Transfer učinkov kognitivnega treninga}

$\mathrm{Na}$ področju študij kognitivnega treninga je bistven transfer, ki predstavlja kakršen koli napredek posameznika pri nalogah, ki niso trenirane (Harvey idr., 2018). Pri bližnjem transferu sta trening in naloga, s katero preverjamo njegov učinek, znotraj istega področja kognitivne sposobnosti (Kelly idr., 2014), drugačen je samo dražljaj in odgovorni format naloge. Pri daljnem transferu pa se izboljšanje odraža v drugi domeni sposobnosti, ki ima s trenirano sposobnostjo manj skupnega (Kelly idr., 2014; Klingberg, 2010).

\section{Namen raziskave}

Namen naše raziskave je bil preveriti učinek kognitivnega računalniškega treninga prostorske navigacije na populaciji aktivnih starejših odraslih. Tovrstna raziskava pri nas še ni bila izvedena, izsledki takšnih raziskav pa so za družbene spremembe, ki smo jim dandanes priča, izjemnega pomena. Staranje prebivalstva namreč s seboj prinaša tudi številna vprašanja, na primer kako posameznikom omogočiti uspešno staranje. Kognitivni računalniški trening se je v dosedanjih raziskavah že izkazal kot učinkovit način za krepitev in ohranjanje kognitivnih sposobnosti različnih populacij. Zato smo želeli preveriti, ali ima računalniški trening prostorske navigacije učinek na določene kognitivne sposobnosti, ki s starostjo upadajo, prav tako pa nas je zanimal njegov vpliv na tiste kognitivne sposobnosti, ki skozi življenje ostajajo razmeroma konstantne. Želeli smo tudi preveriti, kakšen učinek ima tak trening na zadovoljstvo $\mathrm{z}$ življenjem ter kako je učinek takega treninga odvisen od predhodnih kognitivnih sposobnosti.

\section{Metoda}

\section{Udeleženci}

V raziskavi je skupno sodelovalo 46 udeležencev, od tega je bilo 35 žensk in 11 moških. Povprečna starost celotnega vzorca je bila 66,2 leta $(S D=5,1)$. Udeleženke so bile v povprečju stare 66,2 leta $(S D=4,7)$, udeleženci pa 66,2 leta $(S D=6,4)$. Največ udeležencev $(f=18)$ je imelo doseženo 6. stopnjo izobrazbe, 11 jih je imelo 5. stopnjo, 7 oseb je imelo 7. stopnjo, 4 osebe 3 . stopnjo, 3 osebe 2 . stopnjo, 3 osebe 8. stopnjo in 1 oseba 4. stopnjo izobrazbe.

Od vseh udeležencev je v eksperimentalni skupini sodelovalo 25 udeležencev, med njimi 19 žensk in 6 moških. Povprečna starost vseh udeležencev $\mathrm{v}$ tej skupini je bila 65,5 leta $(S D=5,5)$. Ženske so bile v povprečju stare 66,6 leta $(S D=5,6)$, moški pa 62,3 leta $(S D=4,4)$. V kontrolni skupini je bilo 21 udeležencev, od tega 16 žensk in 5 moških. Povprečna starost vseh udeležencev $\mathrm{v}$ tej skupini je bila 67,2 leta $(S D=4,4)$. Ženske so bile v povprečju stare 65,9 leta $(S D=3,6)$, moški pa 72,0 leta $(S D=4,1)$.

Med udeleženci ni bilo nikogar, pri katerem bi s pomočjo presejalnih testov opazili prisotnost pomembnih kognitivnih upadov, zato zaradi zdravstvenih težav ni bilo potrebno nikogar izključiti iz raziskave. 
Želeli bi še izpostaviti, da gre za prvo tovrstno raziskavo opisanega kognitivnega računalniškega treninga pri nas, izvedeno na populaciji aktivnih starejših odraslih. V raziskavo je bil vključen vzorec sicer težje dostopnih starejših odraslih. Osip vzorca je bil majhen, saj je 25 od 30 udeležencev, ki so pričeli s kognitivnim računalniškim treningom, tega tudi uspešno zaključilo.

\section{Pripomočki}

\section{Test risanja ure}

Test risanja ure je presejalni test, ki se zaradi svoje enostavne uporabe širše uporablja za preverjanje prisotnosti demence in drugih kognitivnih disfunkcij. Izvedba testa zahteva verbalno razumevanje, spomin in prostorske sposobnosti $\mathrm{v}$ povezavi s spretnostmi grajenja. Testirancu predložimo predlogo s predhodno narisanim krogom in mu podamo navodilo, da po spominu nariše urna kazalca, ki označujeta določen čas. Pri testu ni časovne omejitve (Agrell in Dehlin, 1998). Koeficienti zanesljivosti med ocenjevalci se gibljejo med 0,75 in 0,99 , koeficienti zanesljivosti $\mathrm{v}$ času pa med 0,70 in 0,94 (Pinto in Peters, 2009).

\section{Kratek preizkus spoznavnih sposobnosti - KPSS (Folstein idr., 1975)}

KPSS je kratek in enostaven test, s katerim pridobimo standardizirano oceno kognitivnega stanja testiranega posameznika v razmeroma kratkem času. Gre za slovensko priredbo testa MMSE (angl. Mini-Mental State Examination; Folstein idr., 1975). Pogosto se uporablja kot kriterijski test za vključitev posameznikov v raziskavo. Sestavljen je iz 11 nalog, ki preverjajo orientacijo v prostoru in času, neposredni in odloženi priklic informacij, miselno sledenje in računanje, poimenovanje, jezik, razumevanje tridelnih navodil, razumevanje pisnih navodil, konstrukcijo enostavnega stavka in prerisovanje geometrijskega lika. Nižji dosežek na preizkusu kaže na večjo verjetnost prisotnosti kognitivnih težav (Granda idr., 2003). Koeficient zanesljivosti v času se giblje med 0,80 in 0,95 (Baek idr., 2016). Za namene naše raziskave smo uporabili zgolj nalogo prostorske in časovne orientacije, $\mathrm{z}$ namenom hitrega ugotavljanja morebitnih kognitivnih upadov pri udeležencih in posledične izključitve iz raziskave.

\section{Demografski vprašalnik}

Da bi bolje spoznali lastnosti vzorca in omogočili iskanje povezav z demografskimi spremenljivkami ter $\mathrm{s}$ tem boljše razumevanje končnih rezultatov študije, smo pripravili demografski vprašalnik, s katerim smo pridobili informacije o spolu udeležencev, njihovi starosti, o tem, kje in s kom bivajo, kakšen je njihov zakonski stan ter kakšna je njihova dosežena stopnja izobrazbe. Pred začetkom reševanja tega vprašalnika so udeleženci tudi generirali svojo šifro, ki je bila sestavljena iz začetnice imena mame, začetnice imena očeta ter osebnega dneva rojstva. To šifro so uporabljali ves čas testiranja in izvajanja kognitivnih računalniških treningov. Določene informacije, kot je domačnost z IKT tehnologijo, smo pridobili ustno ob pogovoru z udeleženci.
Lestvica zadovoljstva z življenjem SWLS (Diener idr., 1985)

Lestvica zadovoljstva z življenjem vključuje pet postavk, o katerih se posameznik opredeli na 7-stopenjski lestvici Likertovega tipa $(1=$ sploh ne drži, 7 = popolnoma drži $)$. Lestvica meri subjektivno splošno zadovoljstvo z življenjem, možen razpon točk, ki jih posameznik lahko doseže, je med 5 in 35. Rezultat na lestvici predstavlja posameznikovo globalno oceno kvalitete lastnega življenja glede na osebne kriterije (Diener idr., 1985). Lestvica ima visoko notranjo konsistentnost, saj se Cronbachov koeficient alfa giblje med 0,79 in 0,89 (Diener idr., 1985). Musek in Avsec (2006) na slovenskem vzorcu ugotavljata, da je koeficient alfa enak 0,83 . Lestvica velja za stabilno v času, saj po dvomesečnem premoru korelacijski koeficient znaša 0,82 (Diener idr., 1985).

\section{Rey-Osterriehtov test kompleksne figure (ROCF; Osterrieth, 1944; Rey, 1941)}

Rey-Osterriehtov test kompleksne figure ROCF je eden najširše uporabljenih nevropsiholoških testov za oceno vidnoprostorskih konstrukcijskih sposobnosti in neverbalnih spominskih sposobnosti. Reproduciranje figure predstavlja kompleksno kognitivno nalogo, ki vključuje organiziranje figure v pomensko zaznavno celoto. Zato je ROCF uporaben za oceno delovanja tistih funkcij frontalnega režnja, ki zahtevajo strateško planiranje in organiziranje. Test vključuje kopiranje kompleksne geometrijske figure in njeno reprodukcijo $\mathrm{s}$ pomočjo spomina. Načinov za izvedbo testa je več, pri čemer smo najprej izvedli kopiranje kompleksne figure, nato pa odložen priklic. Udeleženci o kasnejšem priklicu kompleksne figure vnaprej niso bili obveščeni. S pomočjo kopiranja kompleksne figure lahko merimo pozornost in koncentracijo posameznika, vidnoprostorsko zaznavanje in procesiranje vidnih informacij, vidno-motorično funkcijo, načrtovanje in organizacijske sposobnosti, ki so del izvršilnih funkcij. $\mathrm{Z}$ odloženim priklicem pa preverjamo kodiranje informacij, shranjevanje in sposobnost priklica informacij iz dolgoročnega spomina (Shin idr., 2006). Za vrednotenje testa smo uporabili 36-točkovni sistem (po Meyers in Meyers, 1995), kjer kompleksno figuro razdelimo na 18 elementov in preverjamo njihovo prisotnost ter ustrezno lego na reproducirani kompleksni figuri. V kolikor sta tako pozicija kot prisotnost elementa ustrezni, posamezniku dodelimo 2 točki, 1 točko pa $\mathrm{v}$ primeru, da je zadoščen samo eden od obeh pogojev. Če element ali njegov del manjka in ima hkrati neustrezno lego, ne dodelimo nobene točke (Meyers in Meyers, 1995). Koeficient zanesljivosti znaša 0,96 (Berry idr., 2014).

\section{Test verbalne fluentnosti (Estes, 1974)}

S testom verbalne fluentnosti merimo neposredni priklic informacij, posameznikove verbalne sposobnosti in spomin. Rezultat testa je število priklicanih besed v določeni kategoriji ali odgovorov na podano črko v omejeni časovni enoti. Testi verbalne fluentnosti nam dajejo dober vpogled $\mathrm{v}$ to, kako posameznik organizira svoje mišljenje. Prav tako pa testi, ki vključujejo generiranje besed na izbrano črko, predstavljajo vidik posameznikove uporabe in razvoja najrazličnejših 


\section{Tabela 1}

Uporabljeni kognitivni testi za posamezno kognitivno področje

\begin{tabular}{ll}
\hline Merjeno kognitivno področje & Uporabljeni test \\
\hline Kratkoročni spomin & Test neposrednega pomnjenja zaporedja števil: priklic števil naprej \\
Delovni spomin & Test neposrednega pomnjenja zaporedja števil: priklic števil nazaj \\
Verbalne sposobnosti & Test verbalne fluentnosti \\
Vidnoprostorske sposobnosti & Rey-Osterriehtov test kompleksne figure ROCF \\
Pozornost & Test zamenjave števil s simboli DSST \\
Hitrost procesiranja informacij & Test povezovanja TMT (del A) \\
Izvršilne funkcije & Test povezovanja TMT (del B) \\
\hline
\end{tabular}

strategij pri iskanju novih besed. Primeri učinkovitih strategij so uporaba enakega zloga ali generiranje besed na določeno temo in dodajanje zlogov $\mathrm{k}$ obstoječi besedi ter $\mathrm{s}$ tem tvorba novih besed. Več besed kot uspe posameznik v omejenem času priklicati, boljše so njegove sposobnosti, medtem ko so težave $\mathrm{s}$ fluentnostjo lahko povezane $\mathrm{z}$ morebitnimi poškodbami določenih predelov možganov. Raziskave pa ugotavljajo, da $\mathrm{v}$ primerjavi $\mathrm{z}$ govorno fluentnostjo s starostjo hitreje upada fluentnost pisanja. Težave z generiranjem besed so dobro vidne tudi na področju verbalnih sposobnosti pri posameznikih $\mathrm{z}$ demenco. Za uporabljeni test verbalne fluentnosti koeficient zanesljivosti v času znaša med 0,70 in 0,71 za vse črke, $\mathrm{z}$ izjemo črke A (Estes, 1974). Za namen naše raziskave smo za priklic besed uporabili črko S.

\section{Test povezovanja (TMT; Partington in Leiter, 1949)}

Trail Making Test (TMT) je eden najpogosteje uporabljenih nevropsiholoških testov. Z njim pridobimo podatke o vidnem iskanju, skeniranju, hitrosti procesiranja, mentalni fleksibilnosti in izvršilnih funkcijah. Sestavljen je iz dveh delov, pri čemer prvi del (del A) od posameznika zahteva, da $\mathrm{v}$ naraščajočem zaporedju poveže na predlogi naključno razvrščena števila, drugi del (del B) pa podobno kot prvi prav tako vključuje povezovanje števil v naraščajočem zaporedju, vendar od posameznika zahteva, da izmenično in $\mathrm{v}$ pravem vrstnem redu povezuje števila ter črke, ki so na predlogi. Rezultat meritev je čas, ki ga posameznik potrebuje, da ustrezno dokonča nalogo (Tombaugh, 2004). Posameznikom podamo navodilo, naj nalogo rešujejo tako hitro, kolikor morejo. Koeficienti zanesljivosti se gibljejo med 0,60 in 0,90 . Visoke vrednosti koeficientov ugotavljajo predvsem pri nevropsihiatričnih bolnikih, nizke pa pri bolnikih s shizofrenijo (Goldstein in Watson, 1989).

\section{Test zamenjave števil s simboli - DSST (Wechsler,} 1955)

Test zamenjave števil s simboli je preizkus psihomotoričnih sposobnosti, kjer udeleženec dobi zapisano vrstico $\mathrm{z}$ devetimi številkami in simboli, ki predstavlja ključ (Matarazzo in Herman, 1984). Vsaka od števil ima svoj določen simbol (Lezak, 2012). Udeleženec najprej reši poskusni odsek, nato pa ob našem znaku za začetek nadaljuje z izpolnjevanjem praznih polj. Cilj je, da zapolni čim več praznih polj z ustreznimi simboli pod vsako številko. Rezultat je število pravilno zapisanih simbolov v omejenem času. Test ima visoko zanesljivost in stabilnost v času (Matarazzo in Herman, 1984). Koeficient zanesljivosti v času se giblje med 0,82 in 0,88 , prav tako pa je test občutljiv za prepoznavanje demence in njenega napredovanja. Predstavlja del Wechslerjeve baterije testov inteligentnosti in spomina (Lezak, 2012). V naši raziskavi smo čas reševanja omejili na 60 sekund.

Test neposrednega pomnjenja zaporedja števil (Wechsler, 1997)

S testom neposrednega pomnjenja zaporedij števil merimo obseg neposrednega verbalnega priklica. Vključuje dva različna testa, pri čemer prvi predstavlja priklic v enakem vrstnem redu, kot so števila prvotno podana, medtem ko se od posameznika $\mathrm{v}$ drugem delu testiranja pričakuje priklic podanih števil v obratnem vrstnem redu. Rezultat predstavlja število pravilno priklicanih števil. Priklic zaporedja števil naprej je bolj povezan s pozornostjo kot spominom (Matarazzo in Herman, 1984), priklic zaporedja števil nazaj pa je najuporabnejša naloga za preverjanje kapacitete delovnega spomina (Hilbert idr., 2015). Koeficienti zanesljivosti $\mathrm{v}$ času se gibljejo med 0,66 in $0,89 \mathrm{v}$ odvisnosti od dolžine intervala ter starosti posameznikov (Matarazzo in Herman, 1984).

V tabeli 1 smo pripravili pregled uporabljenih testov po metodi papir-svinčnik po posameznih kognitivnih področjih.

\section{Računalniški kognitivni trening prostorske navigacije}

Za namene raziskave smo uporabili nalogo virtualnega računalniškega labirinta prostorske navigacije $s$ pomočjo računalniškega programa Brain Powered Games: Maze Training(Michigan State University, Games for Entertainment and Learning Lab, 2016). To nalogo smo za našo raziskavo izbrali zato, ker vključuje prostorsko navigacijo, ki zajema multiple kognitivne sposobnosti. Naloga vključuje 10 težavnostnih ravni, ki $\mathrm{v}$ skladu $\mathrm{z}$ uspešnostjo izvedbe postopoma naraščajo. Labirint je sestavljen iz križišč, kjer se lahko odločamo med potjo, ki vodi levo, desno ali naravnost, pri tem pa se po labirintu premikamo s pomočjo tipk na tipkovnici za premikanje naprej, nazaj, levo in desno. 
Tabela 2

Preverjanje izenačenosti eksperimentalne in kontrolne skupine v dejanskih kognitivnih sposobnostih na začetnem testiranju

\begin{tabular}{|c|c|c|c|c|c|c|c|}
\hline Dimenzija & & $M$ & $S D$ & $\min$ & $\max$ & $t(44)$ & $p$ \\
\hline \multirow{2}{*}{ Verbalne sposobnosti } & Eksperimentalna skupina & 14,72 & 3,93 & 6 & 23 & \multirow{2}{*}{0,63} & \multirow{2}{*}{0,53} \\
\hline & Kontrolna skupina & 14,05 & 3,20 & 9 & 20 & & \\
\hline \multirow{2}{*}{ Hitrost procesiranja informacij } & Eksperimentalna skupina & 37,48 & 12,23 & 26 & 82 & \multirow{2}{*}{0,11} & \multirow{2}{*}{0,91} \\
\hline & Kontrolna skupina & 37,05 & 14,90 & 23 & 77 & & \\
\hline \multirow{2}{*}{ Izvršilne funkcije } & Eksperimentalna skupina & 98,56 & 43,46 & 44 & 222 & \multirow{2}{*}{0,88} & \multirow{2}{*}{0,38} \\
\hline & Kontrolna skupina & 87,95 & 37,01 & 42 & 173 & & \\
\hline \multirow{2}{*}{ Pozornost } & Eksperimentalna skupina & 27,88 & 6,86 & 17 & 40 & \multirow{2}{*}{0,14} & \multirow{2}{*}{0,89} \\
\hline & Kontrolna skupina & 27,62 & 5,70 & 19 & 40 & & \\
\hline \multirow{2}{*}{ Vidnoprostorske sposobnosti } & Eksperimentalna skupina & 20,92 & 4,58 & 13 & 33 & \multirow{2}{*}{1,93} & \multirow{2}{*}{0,06} \\
\hline & Kontrolna skupina & 18,43 & 4,11 & 8 & 26 & & \\
\hline \multirow{2}{*}{ Kratkoročni spomin } & Eksperimentalna skupina & 6,08 & 1,12 & 5 & 9 & \multirow{2}{*}{0,82} & \multirow{2}{*}{0,42} \\
\hline & Kontrolna skupina & 5,81 & 1,12 & 4 & 9 & & \\
\hline \multirow{2}{*}{ Delovni spomin } & Eksperimentalna skupina & 4,64 & 0,76 & 3 & 6 & \multirow{2}{*}{1,96} & \multirow{2}{*}{0,06} \\
\hline & Kontrolna skupina & 4,14 & 0,96 & 2 & 6 & & \\
\hline
\end{tabular}

Vsako križišče ima samo eno pravo pot, ostali dve pa vedno vodita v slepo ulico. Začetna raven vključuje tri križišča. Pri zapomnitvi prave poti so posamezniku v pomoč sličice živali, saj se nahajata po dve na vsakem križišču. Za uspešno napredovanje na naslednjo raven mora udeleženec najprej najti pravo pot skozi labirint do cilja, ki ga predstavlja pokal. Potem pa mora to pravo pot brez napake ponoviti še dvakrat. Vsak premik stran s pravilne poti že predstavlja napako. Če udeleženec med ponovitvijo prave poti stori kakšno napako, mora ponovno izpeljati dva brezhibna poskusa. $\mathrm{Z}$ napredovanjem po ravneh narašča tudi število križišč, saj se $\mathrm{Z}$ vsako višjo ravnjo pojavi eno križišče več. S tem se poveča zahtevnost reševanja, saj si mora posameznik zapomniti vedno daljšo pot skozi labirint.

$\mathrm{Z}$ vpisom svoje šifre je udeleženec vsak kognitivni računalniški trening pričel na ravni, ki jo je pri prejšnjem treningu uspešno zaključil. Program virtualnega računalniškega labirinta je beležil tudi napredek posameznika $\mathrm{z}$ določeno šifro.

\section{Postopek}

$\mathrm{V}$ namene raziskave smo sestavili testno baterijo, sestavljeno iz omenjenih kognitivnih preizkusov in demografskega vprašalnika. Za potencialne udeležence smo organizirali uvodno srečanje, kjer so bili seznanjeni z vsemi informacijami o poteku raziskave. V kolikor so se odločili za sodelovanje v raziskavi, so izpolnili tudi obveščeno soglasje. Pred pričetkom izvajanja kognitivnega računalniškega treninga so bili vsi udeleženci individualno testirani in razvrščeni v eksperimentalno (25 udeležencev) ali pasivno kontrolno skupino (21 udeležencev), ki je bila deležna zgolj začetnega in končnega testiranja brez vmesne intervencije.
Začetna testiranja smo pričeli izvajati oktobra 2017, prvi kognitivni računalniški trening pa je bil $\mathrm{v}$ začetku novembra 2017. Z računalniškim kognitivnim treningom prostorske navigacije smo $\mathrm{v}$ prostorih Filozofske fakultete Univerze v Mariboru skupno izvedli 10 kognitivnih treningov po 45 minut. Na vsakem srečanju smo vodili tudi listo prisotnosti in vsak od udeležencev je moral za vključitev v končne analize izvesti najmanj 8 kognitivnih treningov. Tako smo po končanih 10 kognitivnih treningih iz baze podatkov izločili dva udeleženca, ki sta imela manj kot 8 opravljenih kognitivnih treningov, prav tako pa smo bili primorani na osnovi sprotnega beleženja pravilnih premikov v križiščih zaradi neupoštevanja pravil izločiti rezultate še enega udeleženca. Dva udeleženca sta med kognitivnimi treningi zaradi smrti bližnjega in zdravstvenih razlogov prenehala sodelovati $\mathrm{v}$ raziskavi. Tako so bili $\mathrm{v}$ analize vključeni podatki 46 udeležencev. S kognitivnimi računalniškimi treningi smo zaključili v drugi polovici januarja 2018. Sledilo je končno testiranje udeležencev s testi tipa papirsvinčnik na isti lokaciji kot na začetku, s končnim testiranjem pa smo zaključili v februarju 2018.

\section{Analiza podatkov}

Pridobljene podatke smo statistično obdelali s programom IBM SPSS Statistics (verzija 20). Preden smo začeli s preverjanjem zastavljenih hipotez, smo preverili izenačenost eksperimentalne in kontrolne skupine po spolu in starosti. Najprej smo s pomočjo Kolmogorov-Smirnovega testa preverili normalnost porazdelitve spremenljivk. Za odvisne spremenljivke, ki so se normalno porazdeljevale, smo v nadaljevanju za preverjanje izenačenosti skupin $\mathrm{v}$ prvem merjenju uporabili $t$-test za neodvisne vzorce, za tiste odvisne 
Tabela 3

Odstotek spremembe med izmerjenim dosežkom na začetnem in končnem testiranju za posamezne kognitivne sposobnosti ter primerjava med skupinama

\begin{tabular}{|c|c|c|c|c|c|}
\hline Odstotek spremembe & & $M$ & $S D$ & $F(1,43)$ & $p$ \\
\hline \multirow{2}{*}{ Verbalne sposobnosti } & Eksperimentalna skupina & 1,36 & 24,06 & \multirow{2}{*}{0,05} & \multirow{2}{*}{0,831} \\
\hline & Kontrolna skupina & 4,37 & 15,06 & & \\
\hline \multirow{2}{*}{ Hitrost procesiranja informacij } & Eksperimentalna skupina & $-2,34$ & 29,80 & \multirow{2}{*}{0,39} & \multirow{2}{*}{0,537} \\
\hline & Kontrolna skupina & 2,04 & 13,69 & & \\
\hline \multirow{2}{*}{ Izvršilne funkcije } & Eksperimentalna skupina & $-13,12$ & 22,87 & \multirow{2}{*}{3,55} & \multirow{2}{*}{0,066} \\
\hline & Kontrolna skupina & $-0,57$ & 17,62 & & \\
\hline \multirow{2}{*}{ Pozornost } & Eksperimentalna skupina & 9,07 & 16,71 & \multirow{2}{*}{4,82} & \multirow{2}{*}{0,034} \\
\hline & Kontrolna skupina & 0,55 & 8,88 & & \\
\hline \multirow{2}{*}{ Vidnoprostorske sposobnosti } & Eksperimentalna skupina & 30,04 & 35,55 & \multirow{2}{*}{13,41} & \multirow{2}{*}{0,001} \\
\hline & Kontrolna skupina & 4,44 & 20,38 & & \\
\hline \multirow{2}{*}{ Kratkoročni spomin } & Eksperimentalna skupina & 12,30 & 22,07 & \multirow{2}{*}{5,56} & \multirow{2}{*}{0,023} \\
\hline & Kontrolna skupina & 3,88 & 14,74 & & \\
\hline \multirow{2}{*}{ Delovni spomin } & Eksperimentalna skupina & 9,47 & 31,39 & \multirow{2}{*}{5,11} & \multirow{2}{*}{0,029} \\
\hline & Kontrolna skupina & $-1,35$ & 16,43 & & \\
\hline
\end{tabular}

spremenljivke, ki se niso porazdeljevale normalno, pa smo uporabili Mann-Whitneyjev test. Prav tako smo s $t$-testom za neodvisne vzorce preverili izenačenost eksperimentalne in kontrolne skupine po starosti. Pred izvedbo $t$-testa za neodvisne vzorce smo $\mathrm{z}$ Levenovim testom preverili predpostavko o enakosti varianc.

Da bi preverili, ali je prišlo do razlik v dosežkih znotraj eksperimentalne in kontrolne skupine med prvim in drugim merjenjem, smo uporabili parni $t$-test oziroma Wilcoxonov test predznačenih rangov pri tistih odvisnih spremenljivkah, ki niso izpolnile pogojev za izvedbo $t$-testa. V nadaljevanju smo preizkusili več statističnih metod, da bi izmerili učinek izvedene intervencije. V odstotkih smo izračunali spremembo $\mathrm{v}$ dosežkih med začetnim in končnim testiranjem, nato pa smo kot najprimernejšo metodo za ugotavljanje učinka uporabili ANCOVO. Kot kovariat smo uporabili izmerjene dosežke na začetnem testiranju. Za namene testiranja drugih hipotez smo računali povezanost posameznih spremenljivk. Kot dopolnitev $\mathrm{k}$ rezultatom smo dodali še mere velikosti učinka. Uporabili smo Cohenov $d$. Pri interpretaciji njegovih vrednosti smo upoštevali mejne vrednosti 0,20 za majhen učinek, 0,5 za srednji učinek in 0,8 za velik učinek (Cankar in Bajec, 2003).

\section{Rezultati}

Ugotovili smo, da je predpostavki o homogenosti varianc zadoščeno pri vseh predhodnih kognitivnih sposobnostih, razen pri merah delovnega in kratkoročnega spomina. Eksperimentalna in kontrolna skupina se nista statistično značilno razlikovali po spolni sestavi, $t(44)=-0,02, p=0,99$. Prav tako se nista razlikovali po starosti $(U=205, z=-1,27$, $p=0,20)$, kakor tudi ne $\mathrm{v}$ predhodnih kognitivnih sposobnostih (tabela 2).
Predvidevali smo, da se bodo pri udeležencih eksperimentalne skupine $\mathrm{v}$ primerjavi s kontrolno skupino po izvedeni intervenciji kognitivne sposobnosti izboljšale. Naša predvidevanja so se potrdila na področju delovnega spomina, kratkotrajnega spomina, pozornosti in vizualno prostorskih sposobnosti, pri hitrosti procesiranja informacij, izvršilnih funkcijah in verbalnih sposobnostih pa do statistično pomembnih sprememb ni prišlo (tabela 3 ).

Želeli smo tudi preveriti, ali bo pri udeležencih eksperimentalne skupine, ki so imeli prvotno nižje predhodne kognitivne sposobnosti, večji učinek kognitivnega računalniškega treninga. Ugotovili smo, da to drži na področju kratkotrajnega spomina, hitrosti procesiranja informacij, vizualno prostorskih in verbalnih sposobnosti, saj so tisti z nižjimi sposobnostmi v primerjavi s tistimi, ki so imeli višje predhodne kognitivne sposobnosti, na kognitivnem računalniškem treningu bolj napredovali. $\mathrm{Na}$ področju delovnega spomina, pozornosti in izvršilnih funkcij pa nismo ugotovili statistično pomembnih povezanosti (tabela 4).

\section{Tabela 4}

Povezanost izhodiščnih rezultatov kognitivnih sposobnosti in njihovih sprememb pri končnem testiranju

\begin{tabular}{lcc}
\hline Kognitivne sposobnosti & $r$ & $p$ \\
\hline Verbalne sposobnosti & $-0,62$ & 0,001 \\
Hitrost procesiranja informacij & $-0,52$ & 0,008 \\
Izvršilne funkcije & $-0,15$ & 0,464 \\
Pozornost & $-0,37$ & 0,067 \\
Vidnoprostorske sposobnosti & $-0,57$ & 0,003 \\
Kratkoročni spomin & $-0,63$ & 0,001 \\
Delovni spomin & $-0,35$ & 0,089 \\
\hline
\end{tabular}




\section{Slika 1}

Velikost učinka pri primerjavah odstotka spremembe $v$ izmerjenih kognitivnih sposobnostih v eksperimentalni in kontrolni skupini

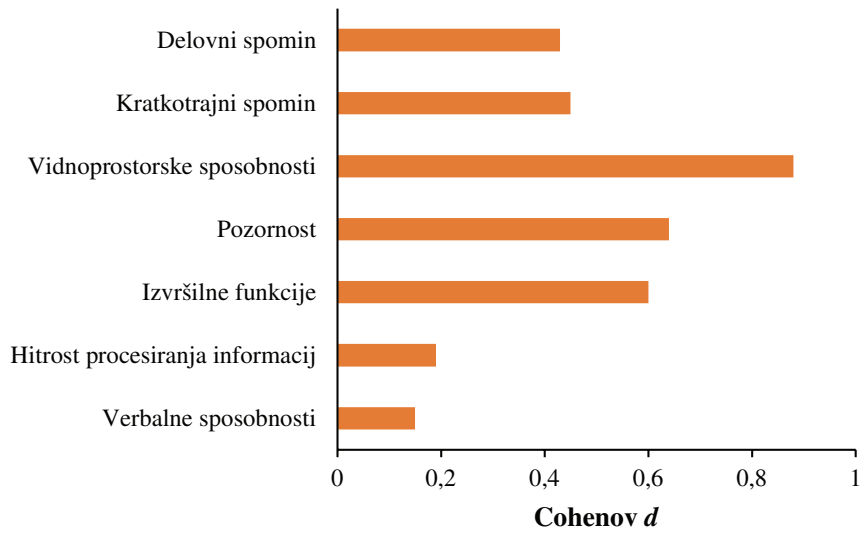

Za konec smo želeli preveriti tudi učinek kognitivnega računalniškega treninga na zadovoljstvo $\mathrm{z}$ življenjem pri eksperimentalni skupini v primerjavi s kontrolno skupino. Predvidevali smo, da bo zadovoljstvo z življenjem v primerjavi z udeleženci v kontrolni skupini večje pri tistih, ki so bili deležni kognitivne intervencije. Izkazalo se je, da je bil pri udeležencih eksperimentalne skupine odstotek spremembe $\mathrm{V}$ zadovoljstvu $\mathrm{z}$ življenjem po izvedeni intervenciji $(M=4,88, S D=13,52)$ višji kot pri kontrolni skupini $(M=-1,29, S D=9,72)$, vendar učinek treninga ni bil stati-stično pomemben, $F(1,42)=1,32, p=0,26$, Cohenov $d=0,30$.

$\mathrm{Na}$ sliki 1 so prikazane vrednosti velikosti učinka, tj. razlik med eksperimentalno in kontrolno skupino $\mathrm{v}$ odstotku spremembe v kognitivnih sposobnostih, do katerih je prišlo od začetnega merjenja do merjenja po izvedenem kognitivnem računalniškem treningu. Ugotovili smo, da je bila velikost učinka največja na področju vidnoprostorskih sposobnosti, najmanjša pa pri verbalnih sposobnostih in hitrosti procesiranja informacij.

\section{Razprava}

V naši raziskavi smo želeli preveriti učinek kognitivnega računalniškega treninga prostorske navigacije na kognitivne sposobnosti ter zadovoljstvo z življenjem pri aktivnih starejših odraslih. Zanimal nas je predvsem daljni transfer učinka treninga na vidnozaznavne sposobnosti, verbalne sposobnosti, kratkoročni in delovni spomin ter na hitrost procesiranja informacij, pozornost in izvršilne funkcije. Pri načrtovanju raziskave smo dosledno upoštevali pogoje za uspešen kognitivni trening, ki so jih izpostavili avtorji podobnih raziskav (Haesner idr., 2015; Lampit idr., 2014; Walton idr., 2015). Osredotočili smo se predvsem na daljni transfer, ki je $\mathrm{v}$ primerljivih študijah redkejši. Kognitivni treningi imajo večji učinek na trenirane kognitivne sposobnosti v primerjavi s kognitivnimi sposobnosti, ki niso bile trenirane neposredno (Mahncke idr., 2006).
Večina ugotovitev naše raziskave glede učinkovitosti kognitivnega računalniškega treninga prostorske navigacije je $\mathrm{v}$ skladu $\mathrm{z}$ ugotovitvami številnih avtorjev (Ball idr., 2002; Ballesteros idr., 2014, 2015; Barban idr., 2016; Basak idr., 2008; Bavelier idr., 2011; Borella idr., 2010; Buiza idr., 2007; Cassavaugh in Kramer, 2009; Cheng idr., 2012; Giuli idr., 2016; Kelly idr., 2014; Lee idr., 2013; Mahncke idr., 2006; Mayas idr., 2014; McAvinue idr., 2013; Miller idr., 2013; Oswald idr., 2006; Uttal idr., 2013; Zelinski idr., 2011). V študiji smo ugotovili pozitiven učinek treninga na delovni in kratkoročni spomin, pozornost in vizualno prostorske sposobnosti, medtem ko učinka kognitivnega računalniškega treninga na verbalne sposobnosti nismo zaznali. Izsledki naše raziskave, ki na področju hitrosti procesiranja informacij in izvršilnih funkcij niso potrdili pomembnih učinkov kognitivnega računalniškega treninga, se uvrščajo med redkejše. Večina objavljenih raziskav potrjuje učinek takšne intervencije, kar bi lahko bila posledica pristranskosti objav (angl. publication bias), ki označuje selektivno objavo raziskovalnih del $\mathrm{s}$ statistično pomembnimi rezultati $\mathrm{v}$ nasprotju s tistimi, ki ne ugotavljajo statistično pomembnih razlik (Rosenthal, 1979; Sala idr., 2019). Prav tako bi lahko vzroke za to, da se določena predvidevanja niso uresničila, pojasnili tudi s spoznanjem Olazarána in sodelavcev (2004), ki ugotavljajo, da bi lahko imeli posamezniki z nižjimi kognitivnimi sposobnostmi večji potencial za učenje in bi s tovrstnim treningom posledično več pridobili. Udeleženci naše raziskave so bili namreč aktivni starejši odrasli, torej posamezniki, ki živijo doma in skrbijo sami zase, prav tako pa so bili zdravi in brez objektivno prepoznanih kognitivnih upadov ter nevrodegenerativnih sprememb.

Prav tako nismo mogli nadzorovati morebitnih kognitivnih aktivnosti, ki so jih bili v času med začetnim in končnim testiranjem morda deležni udeleženci kontrolne skupine in bi lahko vplivale na to, da pri določenih kognitivnih sposobnostih nismo našli statistično pomembnih razlik med spremembami, do katerih je od prvega do drugega merjenja prišlo v eksperimentalni skupini, in spremembami, do katerih je prišlo $\mathrm{v}$ kontrolni skupini.

Kot opozarjajo Uttal idr. (2013), je morda pri določenih posameznikih prišlo tudi do t. i. učinka stropa, ki predpostavlja, da imajo posamezniki $\mathrm{z}$ višjimi predhodnimi kognitivnimi sposobnostmi omejeno možnost napredka in tako kognitivni trening pri takšnih posameznikih ne more imeti takšnega učinka kot pri tistih, ki imajo za napredovanje veliko prostora. Tudi Olazarán idr. (2004), kot je bilo že navedeno, poročajo o večjem potencialu za učenje pri posameznikih z nižjimi prvotnimi kognitivnimi sposobnostmi.

V primerjavi s splošnim pregledom kognitivnih sposobnosti je dobrodošlo podrobneje razdelati vprašanje odnosa med posameznimi sposobnostmi. Nekatere študije (Melby-Lervåg idr., 2016) ugotavljajo, da imajo lahko omejitve v delovnem spominu daljnosežne učinke na druge vidike kognicije, ki jih tako omejujejo pri njihovi nadgradnji. Slednje bi morda lahko povezali tudi z našimi ugotovitvami, saj bi lahko nižji rezultati na meri sposobnosti delovnega spomina kazali na njegove omejitve. Omejitve v delovnem spominu bi se lahko odražale tudi pri nadaljnjem učinku intervencije 
na druge merjene kognitivne sposobnosti, npr. pozornost in izvršilne funkcije, ki so, kot poročajo McCabe idr. (2010), visoko povezane z delovnim spominom. Prav tako je Musek (2012) v svoji raziskavi ugotovil, da kognitivne sposobnosti pozitivno korelirajo med seboj in da upravičeno sklepamo o obstoju njihovih skupnih imenovalcev, ter zaključil, da lahko govorimo o obstoju dveh latentnih dimenzij, od katerih ena povezuje fluidno inteligentnost, hitrost procesiranja informacij, verbalno hitrost in delovni spomin. To dimenzijo bi lahko prepoznali kot široko latentno dimenzijo izvršilnih funkcij, saj je hitrost kognitivnega delovanja povezana predvsem z izvršilnimi funkcijami. To bi lahko pomenilo, da lahko v primeru odsotnosti statistično pomembnih razlik pri določeni kognitivni sposobnosti po izvedeni kognitivni intervenciji govorimo o možnosti, da do spremembe ni prišlo tudi na kognitivnih sposobnostih, ki imajo z omenjeno lastnostjo veliko skupnega.

McDougall in House (2012) poudarjata pomembnost tega, kakšen odnos imajo posamezniki do kognitivnega treninga, in menita, da tisti posamezniki, ki imajo do takšnih intervencij pozitivnejši odnos, bolj vztrajajo in lahko posledično bolj napredujejo.

Ker so bili v našo raziskavo vključeni aktivni starejši odrasli, je v primeru ocen zadovoljstva z življenjem mogoče, da so bile te že $\mathrm{v}$ izhodišču zelo visoke, o čemer poročata Pinquart in Sörensen (2000), pri čemer sklepamo, da jih je težko še zvišati. Naši razmisleki pa gredo tudi v smeri sprememb $\mathrm{v}$ metakognitivnem vidiku, saj je, glede na poročanje udeležencev med celotnim potekom raziskave, mogoče, da so udeleženci, ki so bili deležni kognitivnega računalniškega treninga, skozi trening pridobili realnejše zaznavanje in ocenjevanje lastnih kognitivnih sposobnosti. Nekateri so namreč bili negativno, drugi pa pozitivno presenečeni nad svojimi kognitivnimi sposobnostmi in uspešnostjo pri treningu prostorske navigacije. Tako bi lahko sklepali, da s treningom prihaja tudi do izboljšanja na področju samozaznave kognitivnih sposobnosti.

Ena od omejitev naše raziskave je, da udeleženci niso bili naključno izbrani v vzorec in razporejeni v eksperimentalno in kontrolno skupino, saj so $\mathrm{k}$ naši raziskavi pristopili prostovoljno, prav tako pa glede na interes izbrali sodelovanje v eksperimentalni ali kontrolni skupini. Kot poroča Simons s sodelavci (2016), je mogoče, da na rezultate vplivajo tudi motivacija, pričakovanja, angažiranost posameznikov in podobno. Kot eno večjih omejitev prepoznavamo tudi kratkoročno preverjanje učinkov kognitivnega računalniškega treninga, na kar opozarjajo Ballesteros idr. (2014). Visoka funkcionalnost, neodvisnost ter zdravje vključenih udeležencev pa so najverjetneje otežili doseganje izboljšanja na področju merjenih konstruktov (Buitenweg idr., 2019), pri kontrolni skupini pa nismo mogli nadzorovati možnega pojava placebo efekta. Lahko bi se namreč zgodilo, da je do razlik med začetnim in končnim merjenjem prišlo že samo zaradi zavedanja udeležencev, da so del raziskave.

$\mathrm{V}$ prihodnje bi bilo dobrodošlo usmeriti študije $\mathrm{v}$ preverjanje dolgoročnosti učinkov kognitivnega računalniškega treninga, posameznih oblik kognitivnega treninga in vidikov uporabe pasivne oziroma aktivne kontrolne skupine ter $\mathrm{v}$ sklopu tega vključiti tako objektivni kot subjektivni vidik multiplih kognitivnih sposobnosti. Obenem pa menimo, da bi lahko pomembno pridobitev predstavljale obširnejše povratne informacije udeležencev kognitivnih treningov z namenom sistematične analize in upoštevanja pobud pri načrtovanju podobnih kognitivnih intervencij v prihodnosti.

\section{Zaključek}

Če povzamemo, smo v naši študiji ugotovili daljni transfer učinkov kognitivnega računalniškega treninga prostorske navigacije na sposobnosti delovnega in kratkoročnega spomina, pozornost in vidnoprostorske sposobnosti, medtem ko učinka tega treninga na verbalne sposobnosti nismo zaznali. Pri presojanju učinkov kognitivnega računalniškega treninga so se predhodne kognitivne sposobnosti izkazale kot pomembne. Naša raziskava je potrdila učinkovitost kognitivnega računalniškega treninga na specifični populaciji starejših odraslih na več področjih. Kognitivni računalniški trening prostorske navigacije bi bilo z namenom širše dostopnosti in vzdrževanja kognitivnih sposobnosti ter subjektivnega zadovoljstva $\mathrm{z}$ življenjem pri aktivni starajoči se populaciji priporočljivo umestiti v vsakdanjo praktično uporabo. Ta bi lahko bila del ponudbe dnevnih centrov za starejše odrasle, kakor tudi v domovih za starejše in $\mathrm{v}$ lokalnih društvih upokojencev. Glede na pričujoče rezultate bi vključenim starejšim odraslim lahko pomagal pri treningu kognitivnih sposobnosti, vzdrževanju določene ravni kognitivnega funkcioniranja in tudi pri socialnem vključevanju v skupino. Tako bi z implementacijo kognitivnih treningov naslovili širše delovanje starejših odraslih, katerih število v naši družbi narašča, in $\mathrm{s}$ tem morebiti doprinesli $\mathrm{k}$ njihovi kvaliteti življenja.

\section{Literatura}

Agrell, B. in Dehlin, O. (1998). The clock-drawing test. Age and Ageing Advance Access, 27(3), 399-403.

Baddeley, A. (1992). Working memory. Science, 255(5044), $556-559$.

Baek, M. J., Kim, K., Park, Y. H. in Kim, S. Y. (2016). The validity and reliability of mini-mental state examination-2 for detecting mild cognitive impairment and Alzheimer's disease in a Korean population. PLoS One, 11(9), članek e0163792.

Ball, K., Berch, D. B., Helmers, K. F., Jobe, J. B., Leveck, M. D., Marsiske, M., Morris, J. N., Rebok, G. W., Smith, D. M., Tennstedt, S. L., Unverzagt, F. W. in Willis, S. L. (2002). Effects of cognitive training interventions with older adults: A randomized controlled trial. The Journal of the American Medical Association, 288(18), 2271-2281.

Ball, K., Edwards, J. D. in Ross, L. A. (2007). The impact of speed of processing training on cognitive and everyday functions. The Journals of Gerontology, Series B: Psychological Science and Social Science, 62, 19-31.

Ballesteros, S., Mayas, J., Prieto, A., Toril, P., Pita, C., Ponce de Leon, L., Reales, J. M. in Waterworth, J. A. (2015). A randomized controlled trial of brain training with nonaction video games in older adults: Results of the 3-month follow-up. Frontiers in Aging Neuroscience, 7, 45. 
Ballesteros, S., Prieto, A., Mayas, J., Toril, P., Pita, C., Ponce de Leon, L., Reales, J. M. in Waterworth, J. (2014). Brain training with non-action video games enhances aspects of cognition in older adults: Randomized controlled trial. Frontiers in Aging Neuroscience, 6, 277.

Barban, F., Annicchiarico, R., Pantelopoulos, S., Federici, A., Perri, R., Fadda, L., Carlesimo, G. A., Ricci, C., Giuli, S., Scalici, F., Turchetta, C. S., Adriano, F. , Lombardi, M. G., Zaccarelli, C., Cirillo, G., Passuti, S., Mattarelli, P., Lymperopoulou, O., Sakka, P., ... Caltagirone, C. (2016). Protecting cognition from aging and Alzheimer's disease: A computerized cognitive training combined with reminiscence therapy. International Journal of Geriatric Psychiatry, 31(4), 340-348.

Basak, C., Boot, W. R., Voss, M. W. in Kramer, A. F. (2008). Can training in a real-time strategy video game attenuate cognitive decline in older adults? Psychology and Aging, 23(4), 765-777.

Bavelier, D., Green, C. S., Han, D. H., Renshaw, P., Merzenich, M. M. in Gentile, D. A. (2011). Brains on video games. Nature Reviews Neuroscience, 12(12), 763-768.

Berry, D. T. R., Allen, R. S. in Schmitt, F. A. (2014). ReyOsterrieth complex figure: Psychometric characteristics in a geriatric sample. The Clinical Neuropsychologist, 5(2), 143-153.

Borella, E., Carretti, B., Riboldi, F. in De Beni, R. (2010). Working memory training in older adults: Evidence of transfer and maintenance effects. Psychology and Aging, 25(4), 767-778.

Brickman, A. M. in Stern, Y. (2009). Aging and memory in humans. V Larry R. Squire (ur.), Encyclopedia of Neuroscience (str. 175-180). Academic Press.

Buitenweg, J. I. V., Van De Ven, R. M., Ridderinkhof, K. R. in Murre, J. M. J. (2019). Does cognitive flexibility training enhance subjective mental functioning in healthy older adults? Aging, Neuropsychology, and Cognition, 26(5), 688-710.

Buiza, C., Etxeberria, I., Galdona, N., Gonzalez, M. F., Manchola, E. A., López de Munain, A., Urdaneta, E. in Yanguas, J. J. (2007). A randomized, two-year study of the efficacy of cognitive intervention on elderly people: The Donostia longitudinal study. International Journal of Geriatric Psychiatry: A Journal of the Psychiatry of Late Life and Allied Sciences, 23(1), 85-94.

Burgener, S. C., Yang, Y., Gilbert, R. in Marsh-Yant, S. (2008). The effects of a multimodal intervention on outcomes of persons with early-stage dementia. American Journal of Alzheimer's Disease and Other Dementias, 23(4), 382-394.

Buschkuehl, M., Jaeggi, S. M., Hutchison, S., Perrig-Chiello, P., Däpp, C., Müller, M., Breil, F., Hoppeler, H. in Perrig, W. J. (2008). Impact of working memory training on memory performance in old-old adults. Psychology and Aging, 23(4), 743-753.

Calkins, A. W., McMorran, K. E., Siegle, G. J. in Otto, M. W. (2015). The effects of computerized cognitive control training on community adults with depressed mood. Behavioural and Cognitive Psychotherapy, 43(5), 578-589.
Cankar, G. in Bajec, B. (2003). Velikost učinka kot dopolnilo testiranju statistične pomembnosti razlik [Effect size as a supplement to statistical significance testing]. Psihološka obzorja, 12(2), 97-112.

Carretti, B., Borella, E., Zavagnin, M. in De Beni, R. (2011). Impact of metacognition and motivation on the efficacy of strategic memory training in older adults: Analysis of specific, transfer and maintenance effects. Archives of Gerontology and Geriatrics, 52(3), e192-e197.

Cassavaugh, N. D. in Kramer, A. F. (2009). Transfer of computer-based training to simulated driving in older adults. Applied Ergonomics, 40(5), 943-952.

Cheng, Y., Wu, W., Feng, W., Wang, J., Chen, Y., Shen, Y., Li, Q., Zhang, X. in Li, C. (2012). The effects of multidomain versus single-domain cognitive training in nondemented older people: A randomized controlled trial. Biomedcentral Medicine, 10(1), 1-13.

Corbett, A., Owen, A., Hampshire, A., Grahn, J., Stenton, R., Dajani, S., Burns, A., Howard, R., Wlliams, N., Williams, G. in Ballard, C. (2015). The effect of fan online cognitive training package in healthy older adults: An online randomized controlled trial. Journal of the American Medical Directors Association, 16(11), 990-997.

Diener, E., Emmons, R. A., Larsen, R. J. in Griffin, S. (1985). The satisfaction with life scale. Journal of Personality Assessment, 49(1), 71-75.

Edwards, J., Wadley, V., Myers, R. E., Roenker, D. L., Cissell, G. in Ball, K. (2002). Transfer of a speed of processing intervention to near and far cognitive functions. Gerontology, 48(5), 329-340.

Estes, W. K. (1974). Learning theory and intelligence. American Psychologist, 29(10), 740-749.

European Commission. (2018, maj). The 2018 ageing report: Economic \& budgetary projections for the 28 EU member states (2016-2070) (Institutional paper 079). https://ec.europa. eu/info/sites/info/files/economy-finance/ip079_en.pdf

Folstein, M. F., Folstein, S. E. in McHugh, P. R. (1975). "Mini-mental state": A practical method for grading the cognitive state of patients for the clinician. Journal of Psychiatric Research, 12(3), 189-198.

Giuli, C., Papa, R., Lattanzio, F. in Postacchini D. (2016). The effects of cognitive training for elderly: results from My Mind Project. Rejuvenation Research, 19(6), 458-494.

Goldstein, G. in Watson, J. R. (1989). Test-retest reliability of the Halstead-Reitan Battery and the WAIS in a neuropsychiatric population. Clinical Neuropsychologist, 3(3), 265-272.

Granda, G., Mlakar, J. in Vodušek, D. B. (2003). Kratek preizkus spoznavnih sposobnosti - usmerjanje pri preiskovancih, starih od 55 do 75 let (i) [The Slovene version of Mini Mental State Examination - Standardization on volunteers from 55 to 75 years old (i)]. Zdravniški vestnik, 72(10), 575-581.

Haesner, M., Steinert, A., O'Sullivan, J. L. in Weichenberger, M. (2015). Evaluating an online cognitive training platform for older adults: User experience and implementation requirements. Journal of Gerontological Nursing, 41(8), 32-33. 
Hardy, J. L., Nelson, R. A., Thomason, M. E., Sternberg, D. A., Katovich, K., Farzin, F., in Scanlon, M. (2015). Enhancing cognitive abilities with comprehensive training: A large, online, randomized, active-controlled trial. PLoS One, 10(9), članek e0134467.

Harvey, P. D., McGurk, S. R., Mahncke, H. in Wykes, T. (2018). Controversies in computerized cognitive training. Biological Psychiatry: Cognitive Neuroscience and Neuroimaging, 3(11), 907-915.

Hilbert, S., Nakagawa, T. T., Puci, P., Zech, A. in Bühner, M. (2015). The digit span backwards task: Verbal and visual cognitive strategies in working memory assessment. European Journal of Psychological Assessment, 31, 174-180.

Jackson, J. J., Hill, P. L., Payne, B. R., Roberts, B. W. in StineMorrow, E. A. L. (2012). Can an old dog learn (and want to experience) new tricks? Cognitive training increases openness to experience in older adults. Psychology and Aging, 27(2), 286-292.

Jak, A. J., Seelye, A. M. in Jurick, S. M. (2013). Crosswords to computers: A critical review of popular approaches to cognitive enhancement. Neuropsychology Review, 23(1), 13-26.

Karbach, J. in Verhaeghen, P. (2014). Making working memory work: A meta-analysis of executive-control and working memory training in older adults. Psychological Science, 25(11), 2027-2037.

Kelly, M. E., Loughrey, D., Lawlor, B. A., Robertson, I. H., Walsh, C. in Brennan, S. (2014). The impact of cognitive training and mental stimulation on cognitive and everyday functioning of healthy older adults: A systematic review and meta-analysis. Ageing Research Review, 15, $28-43$

Klimova, B. (2016). Computer-based cognitive training in aging. Frontiers in Aging Neuroscience, 8, 1-6.

Klingberg, T. (2010). Training and plasticity of working memory. Trends in Cognitive Sciences, 14(7), 317-324.

Klusmann, V., Evers, A., Schwarzer, R., Schlattmann, P., Reischies, F.M., Heuser, I. in Dimeo, F. C. (2010). Complex mental and physical activity in older women and cognitive performance: A 6-month randomized controlled trial. The Journals of Gerontology, 65(6), 680-688.

Kueider, A. M., Parisi, J. M., Gross, A. L. in Rebok, G. W. (2012). Computerized cognitive training with older adults: A systematic review. PLoS One, 7(7), članek e40588.

Lampit, A.,Hallock, H. in Valenzuela, M.(2014). Computerized cognitive training in cognitively healthy older adults: A systematic review and meta-analysis of effect modifiers. PLoS Medicine, 11(11), članek e1001756.

Lee, T. S., Goh, S. J. A., Quek, S. Y., Phillips, R., Guan, C., Cheung, Y. B., Feng, L., Teng, S. S. W., Wang, C. C., Chin, Z. Y., Zhang, H., Ng, T. P., Lee, J., Keefe, R. in Krishnan, K. R. R. (2013). A brain-computer interface based cognitive training system for healthy elderly: A randomized control pilot study for usability and preliminary efficacy. PLoS One, 8(11), članek e79419.

Levinson, D. J. (1986). A conception of adult development. American Psychologist, 41(1), 3-13.
Lezak, M. D. (2012). Neuropsychological Assessment. Oxford University Press.

Lithfous, S., Dufour, A. in Despres, O. (2013). Spatial navigation in normal aging and the prodromal stage of Alzheimer's disease: Insights from imaging and behavioral studies. Ageing Research Reviews, 12(1), 201-213.

Litwin, H. in Shiovitz-Ezra, S. (2006). The association between activity and well-being in later life: What really matters? Ageing and Society, 26, 225-242.

Mahncke, H. W., Connor, B. B., Appelman, J., Ahsanuddin, O. N., Hardy, J. L., Wood, R.A., Joyce, N. M., Boniske, T., Atkins, S. M. in Merzenich, M. M. (2006). Memory enhancement in healthy older adults using a brain plasticity-based training program: A randomized, controlled study. Proceedings of the National Academy of Sciences of the United States of America, 103(33), 12523-12528.

Maillot, P., Perrot, A. in Hartley, A. (2012). Effects of interactive physical-activity video game training on physical and cognitive function in older adults. Psychology and Aging, 27(3), 589-600.

Martin, M., Clare, L., Altgassen, A. M., Cameron, M. H. in Zehnder, F. (2011). Cognition-based interventions for healthy older people and people with mild cognitive impairment. The Cochrane Database of Systematic Reviews 2011, Issue 1, Art. No. CD006220.

Matarazzo, J. D. in Herman, D. O. (1984). Base rate data for the WAIS-R: Test - retest stability and VIQ-PIQ differences. Journal of Clinical Neuropsychology, 6(4), 351-366.

Mayas, J., Parmentier, F. B., Andres, P. in Ballesteros, S. (2014). Plasticity of attentional functions in older adults after non-action video game training: A randomized controlled trial. PLoS One, 9(3), članek e92269.

McAvinue, L. P., Golemme, M., Castorina, M., Tatti, E., Pigni, F. M., Salomone, S., Brennan, S. in Robertson, I. H. (2013). An evaluation of a working memory training scheme in older adults. Frontiers in Aging Neuroscience, 5,20 .

McCabe, A. P., Roediger, H. L., McDaniel, M. A., Balota, D. A. in Hambrick, D. Z. (2010). The relationship between working memory capacity and executive functioning: Evidence for a common executive attention construct. Neuropsychology, 24(2), 222-243.

McDougall, S. in House, B. (2012). Brain training in older adults: Evidence of transfer to memory span performance and pseudo-Matthew effects. Aging, Neuropsychology and Cognition, 19(1-2), 195-221.

Melby-Lervåg, M., Redick, T. S. in Hulme, C. (2016). Working memory training does not improve performance on measures of "far transfer": Evidence from a metaanalytic review. Perspectives on Psychological Science, 11(4), 512-534.

Meyers, J. E. in Meyers, K. R. (1995). Rey complex figure test and recognition trial: Professional manual. Psychological Assessment Resources. 
Michigan State University, Games for Entertainment and Learning Lab. (2016). Brain powered games: Maze training [računalniški program]. https:// brainpoweredgames.msu.edu/

Miller, K. J., Dye, R. V., Kim, J., Jennings, J. L., O’Toole, E., Wong, J. in Siddarth, P. (2013). Effect of a computerized brain exercise program on cognitive performance in older adults. The American Journal of Geriatric Psychiatry, 21(7), 655-663.

Mowszowski, L., Batchelor, J. in Naismith, S. L. (2010). Early intervention for cognitive decline: Can cognitive training be used as a selective prevention technique? International Psychogeriatrics, 22(4), 537-548.

Musek, J. (2012). Kognitivne sposobnosti: Sodobni pogled na njihovo strukturo in povezanost $\mathrm{s}$ starostjo in intelektualnim staranjem [Cognitive abilities: A recent look at their structure and their connections with age and intellectual aging]. Anthropos, 44(3/4), 103-123.

Musek, J. in Avsec, A. (2006). Osebnost, samopodoba in psihično zdravje [Personality, self-concept, and psychological health]. Anthropos, 38(1-2), 51-75.

Nacionalni inštitut za javno zdravje. (2016, maj). Telesna dejavnost za zdravo in aktivno staranje [Physical activity for healthy and active aging]. Nacionalni inštitut za javno zdravje. https://www.nijz. si/sl/telesna-dejavnost-za-zdravo-in-aktivno-staranje

Nouchi, R., Taki, Y., Takeuchi, H., Hashizume, H., Akitsuki, Y., Shigemune, Y., Sekiguchi, A., Kotozaki, Y., Tsukiura, T., Yomogida, Y. in Kawashima, R. (2012). Brain training game improves executive functions and processing speed in the elderly: A randomized controlled trial. PLoS One, 7(1), članek e29676.

Olazarán, J., Muñiz, R., Reisberg, B., Peña-Casanova, J. del Ser, T., Cruz-Jentoft, A. J., Serrano, P., Navarro, E., García de la Rocha, M. L., Frank, A., Galiano, M., Fernández-Bullido, Y., Serra, J. A., González-Salvador, M. T. in Sevilla, C. (2004). Benefits of cognitive-motor intervention in $\mathrm{MCI}$ and mild to moderate Alzheimer disease. Neurology, 63(12), 2348-2353.

Osterrieth, P. A. (1944). Le test de copie d'une figure complexe; Contribution à l'étude de la perception et de la mémoire [Test of copying a complex figure; Contribution to the study of perception and memory]. Archives de Psychologie, 30, 206-356.

Oswald, W., Gunzelmann, T., Rupprecht, R. in Hagen, B. (2006). Differential effects of single versus combined cognitive and physical training with older adults: The SimA study in a 5-year perspective. European Journal of Ageing, 3(4), 179-192.

Palta, P., Snitz, B. in Carlson, M. C. (2016). Neuropsychologic assessment. V C. Rosano, M. A. Ikram in M. Ganguli (ur.), Handbook of Clinical Neurology (str. 107-119). Elsevier.

Park, D. C. (2000). Basic mechanisms accounting for agerelated decline in cognitive functions. V D. C. Park in N. Schwarz (ur.), Cognitive aging: A primer (str. 3-21). Psychology Press.

Partington, J. E. in Leiter, R. G. (1949). Partington's Pathways Test. Psychological Service Center Journal, 1, 11-20.
Pečjak, V. (1998). Psihologija tretjega življenjskega obdobja [Psychology of 3rd life period]. Znanstveni inštitut Filozofske fakultete Univerze v Ljubljani.

Peretz, C., Korczyn, A. D., Shatil, E., Aharonson, V., Birnboim, S. in Giladi, N. (2011). Computer-based, personalized cognitive training versus classical computer games: A randomized double-blind prospective trial of cognitive stimulation. Neuroepidemiology, 36(2), 91-99.

Pinquart, M. in Sörensen, S. (2000). Influences of socioeconomic status, social network, and competence on subjective well-being in later life: A meta-analysis. Psychology and Aging, 15(2), 187-224.

Pinto, E. in Peters, R. (2009). Literature review of the clock drawing test as a tool for cognitive screening. Dementia and Geriatric Cognitive Disorders, 27(3), 201-213.

Rey, A. (1941). L'examen psychologique dans les cas d'encéphalopathie traumatique. (Les problems.) [The psychological examination in cases of traumatic encepholopathy. Problems]. Archives de Psychologie, 28, 215-285.

Richmond, L. L., Morrison, A. B., Chein, J. M. in Olson, I. R. (2011). Working memory training and transfer in older adults. Psychology and Aging, 26(4), 813-822.

Rosenthal, R. (1979). The file drawer problem and tolerance for null results. Psychological Bulletin, 86(3), 638-641.

Sala, G., Aksayli, N. D., Tatlidil, K. S., Tatsumi, T., Gondo, Y. in Gobet, F. (2019). Near and far transfer in cognitive training: A second-order meta-analysis. Collabra: Psychology, 5(1), 18.

Salthouse, T. A. (1996). The processing-speed theory of adult age differences in cognition. Psychological Review, 103(3), 403-428.

Sedmak, M., Bogataj, V. in Černelč, E. (2017, november). Skupnostne oblike preživljanja časa starejših [Community forms of older adults' spending time] [povzetek konferenčnega prispevka]. V V. Sitar (ur.), Zbornik prispevkov strokovnega programa 17. festivala za tretje življenjsko obdobje, Ljubljana, Slovenija [Proceedings of the 17th Third Life Period Festival, Ljubljana, Slovenia]. Proevent.

Shin, M., Park, S., Park, S., Seol, S. in Kwon, J. S. (2006). Clinical and empirical applications of the Rey-Osterrieth complex figure test. Nature Protocols, 1(2), 892-900.

Simons, D. J., Boot, W. R., Charness, N., Gathercole, S. E., Chabris, C. F., Hambrick, D. Z. in Stine-Morrow, E. A. (2016). Do »brain-training« programs work? Psychological Science in the Public Interest, 17(3), 103-186.

Smith, J., Fleeson, W., Geiselmann, B., Settersten, R. A. in Kunzmann, U. (1999). Sources of well-being in very old age. V P. B. Baltes in K. U. Mayer (ur.), The Berlin aging study: Aging from 70 to 100 (str. 450-471). Cambridge University Press.

Stenner, P., McFarguhar, T. in Bowling, A. (2011). Older people and »active ageing«: Subjective aspects of ageing actively. Journal of Health Psychology, 16(3), 467-477.

Tombaugh, T. N. (2004). Trail making test A and B: Normative data stratified by age and education. Archives of Clinical Neuropsychology, 19(2), 203-214. 
Uttal, D. H., Meadow, N. G., Tipton, E., Hand, L. L., Alden, A. R, Warren, C. in Newcombe, N.S. (2013). The malleability of spatial skills: A meta-analysis of training studies. Psychological Bulletin, 139(2), 352-402.

Vance, D., Dawson, J., Wadley, V., Edwards, J., Roenker, D., Rizzo, M. in Ball, K. (2007). The accelerate study: The longitudinal effect of speed of processing training on cognitive performance of older adults. Rehabilitation Psychology, 52(1), 89-96.

Walker, A. (2006). Active ageing in employment: Its meaning and potential. Asia-Pacific Review, 13(1), 78-93.

Walton, C., Kavanagh, A., Downey, L. A., Lomas, J., Camfield, D. A. in Stough, C. (2015). Online cognitive training in healthy older adults: A preliminary study on the effects of single versus multi-domain training. Translational Neuroscience, 6(1), 13-19.

Wechsler D. (1955). Wechsler Adult Intelligence Scale Manual. Psychological Corporation.

Wechsler, D. (1997). WAIS-3, WMS-3: Wechsler adult intelligence scale, Wechsler memory scale: Technical manual. Psychological Corporation.

Winocur, G., Craik, F. I., Levine, B., Robertson, I. H., Binns, M. A., Alexander, M., Black, S., Dawson, D., Palmer, H., McHugh, T. in Stuss, D. T. (2007). Cognitive rehabilitation in the elderly: Overview and future directions. Journal of the International Neuropsychological Society, 13(1), $166-171$.

Wolinsky, F. D., Unverzagt, F. W., Smith, D. M., Jones, R., Stoddard, A. in Tennstedt, S. L. (2006). The ACTIVE cognitive training trial and health-related quality of life: Protection that lasts for 5 years. The Journals of Gerontology, Series A: Biological Sciences and Medical Sciences, 61(12), 1324-1329.

Zelinski, E. M., Spina, L. M., Yaffe, K., Ruff, R., Kennison, R. F., Mahncke, H. W. in Smith, G. E. (2011). Improvement in memory with plasticity-based adaptive cognitive training: results of the 3-month follow-up. Journal of the American Geriatrics Society, 59(2), 258-265. 